\title{
VIOLENCE AGAINST WOMEN, EQUALITY OF GENDER AND SOCIAL ETHICS
}

\author{
Fransiska Novita Eleanora \\ Faculty of Law Bhayangkara University Jakarta Raya \\ vita_eleanor@yahoo.com
}

\begin{abstract}
Humans are created interdependent and complement each other, as well as mutual respect and respect that is what is called a social creature, and live in pairs between men and women to continue offspring, which is a natural human nature that has been hereditary. But in reality, in social life, a woman often gets inhumane treatment, be it in public life or domestic life, is treated rudely, and impressed as not considered, women are very vulnerable to violence, whether physical violence, psychic violence, violence sexual even neglect of household. Or even men do not respect women in the realm of the outside or inside the dwelling. Result in a significant difference to gender equality itself. The most important and protected women's rights are freedom, being treated equally in the eyes of law, teaching and education is absolute, as well as health, legal certainty and justice and legal certainty. Social ethics arises in everyone, according to their nature and character. Human nature can be seen from their actions in treating and respecting others, especially treating the opposite sex, not in accordance with ethics and social sense, then the person is considered disrespectful to others. The literature study is the method used in this study is to have a purpose to know gender and its equality be the cause of violence against women, and its relation to social ethics. The result is a patriarchal culture that assumes that men as rulers, while women are in a weak position or are perceived as "male" owners, and social ethics greatly affect respect for women, where social ethics strongly determines one's behavior and how to respect and respect for women's rights.
\end{abstract}

Keywords: woman, equality, gender, ethics

\section{Introduction}

The issues of the World that are discussing are Humanity and Human Rights, especially regarding citizens and their protection, in the sense of citizens without discrimination. Everyone, wherever he or she lives, shall recognize his or her freedom and the existence of others, this is implied in Article 1 of Law No.39 of 1999 concerning the granting of freedom of rights and their representation to human beings in terms of human existence and attributes called the right which shall always be protected and safeguarded by the State, respected, respected, safeguarded and protected, due to repeal, the Law shall be preserved and protected, and the Goverment, because everyone is the creation and creation of God Almighty, for the honor and protection of human dignity. The law prohibits and gives orders for actions relating to discrimination against women's lives and states that women's rights in this law are women and their human rights.

The 1st Article contained in the provisions of CEDAW mentioning (Women's Convention on Forms of Violence and the Relationship between or Elimination) means that differences in women are given differences in terms of discrimination, the existence of exceptions or there are gender and its restrictions, or different types of gamut aiming or produce and reduce or recognize 
neglect, pleasure or human rights as the basis of cultural, economic, social, political, social and civil liberties. In other words by women regardless of their marriage and status, there are differences and inequalities that superior men are and thus forms of torture because there is no adequate prevention and protection for women's rights.

Violence and cruelty committed against women, whether committed by their own husbands or male superiors over women. Vulnerable to violence is directed at women because their nature is considered powerless, so weak, while men are highly character, superior and mighty. This can be regarded as a violation of the rights of women, and is very contrary to human values, legal and social ethics of human rights is also inseparable from the influence of social ethics in human life, because social ethics is a form of manifestation of human behavior, and how a person's reflection treats others by virtue of their nature and character, the lack of social ethics in a person can be affected by the decline of morality and humiliation, especially the opposite sex, that is, women can influence violence, because women are very weak, must be protected, vulnerable and from acts beyond the limits of humanity. rules applicable in a region may be followed according to social ethics and not contradictory. To maintain a good life around the environment, must have their own rules.

\section{Formulation of The Problem}

Is domestic violence dominated by social ethics?

\section{Discussion}

\section{Gender equality}

Gender can be termed or interpreted by different interpretations and often / often leads to unbalanced responses / answers, in other words disproportionate. The word gender in Indonesian comes from English literally "gender" which means gender. Justice is a victory milestone of every human being, and the side of justice is defined as the same, non-selective, and equally equal right. Justice here there is no discriminatory action, must treat the weak in the same way, Aristotle says that man is a social creature (zoon politicon), who cannot live alone, but must depend on others, and mutual need between with others, and also to continue his offspring. Broadly speaking, the definition of gender justice is the treatment of fair women equal to the men.

Gender Justice There is no perception to look at each other differently, all in the view of the law and the rules must always be treated equally, in accordance with their respective roles. In 
social life, gender equality is defined as the same principle and living in peace and having similarities and conditions to participate in political, legal, economic, socio-cultural, educational and defense activities and national security (national defense and security) and equality in the enjoyment of results development, and get the opportunity and rights as the personality of all the people of Indonesia, the nation with his life is appropriate. This gender equality cannot be separated from social ethics that includes behavior and morals, especially to women, and men must respect each other, mutual respect and mutual understanding and will cannot be imposed for personal or group interests.

It is not assumed that women are weak, helpless, then treated as casually as "birds in a golden cage" and as if they are ignored, more dominant to have total and total protection, especially the protection of violence often experienced by women, whether in physical protection, psychological violence, neglect of household and economy ${ }^{1}$. Gender equality can be eliminated, if there is a sense of awareness to feel that they are the creation of God Almighty, and have the same rights ${ }^{2}$, do not assume that the weak cannot do anything, the assumption is wrong, because the weak is not necessarily weak, and incapable of doing anything, such perceptions must always be removed from thought.

\section{The forms of gender inequality are}

- Marginalization, the assumption that women as supplementary workers, and this is based on poverty, with weak female nature so that assumptions need not be used very complicated, so as not to harm women

- $\quad$ Stereo Type / Negative labeling is defined as the appointment of unequal or overlapping power relations and intends to dominate or conquer other parties, usually the other parties referred to here are none other than women

- Violence, which may be physically or non-physically assaulted by a family institution, or a group or the like, even a State or other gender Society.

- Discrimination/ subordination, assumptions or judgments and even the roles performed by a gender, are very low, and sometimes often unappreciated.

- Dual burden, tends to be an injustice because the workload that must be accepted or charged to women (one sex) is very much when compared with the other sex

\footnotetext{
1 https://www.zimlii.org/zw/journal/\%5Bnode\%3Afield_jpubdate\%3Acustom\%3AY/zimbabwe-electronic-law-journal-vol-i2016-all-volume 1 Tahun 2016
} 


\section{Violence}

Many opinions provide terminology, that acts of violence will inevitably lead to physical violence, while psychic attacks also include violence, severe abuse caused by violence can result in death. Within the household and its scope as defined in the Domestic Violence Ordinance and its Abolition Or Domestic Violence Number 23 Year 2004 states that violence also includes violence in neglect and sexual violence in the household, where a person is capable of acting in the absence of feelings and open conscience, and respect is lacking, and aims to torture others. Proof of the existence of acts of violence, with the request of the victim's to the physician, (especially against physical violence), even in the provisions of Indonesian Criminal Code (KUHP) in Article 90, is mentioned with "Heavy Wounds" is wounds which may cause: a) defects, b) loss of one of the five senses, c) paralysis d) change of mind (mind) e) woman who miscarries/loses the fetus.

Violence causes a person to act harshly, unethical and wants to be respected or respected in his or her surroundings and association. The selfish attitude that exists within a person leads to carelessness to the surrounding environment, selflessness and as though dictatorial. Violence is a crime against the human body and soul, the actions that a person undertakes to cause violence, it can be said that his moral values are lost, his emotions are explosive, and done by hitting, slapping, kicking, grabbing, The act is a crime where the perpetrator will be given a sanction/punishment in accordance with his actions.

\section{Social Ethics}

Social Ethics is a community that has a distinctive characteristic and applies only to a person and depends on where the person lives by using the customs that prevail in his residence, an ethic that teaches his attitude toward his neighbor, to help each other, empathize and can alleviate the suffering of those who experience difficulties in his life, in other words identical social ethics can be interpreted to lighten the burden of others, appreciate and high attention.

\section{The Importance of Social Ethics}

The Importance of Social Ethics

(a) A person living in a place with certain customs must comply with the social ethics of the place. It aims to maintain harmony among members of the community. 
(b) Every action we take must always be in accordance with the prevailing social ethics in the area. To keep a good life in the environment, there is a rule of their own.

\section{Countermeasures}

Gender control and equality and social ethics are closely intertwined, if each side is aware of itself, and fosters mutual respect for one another, and realizes as a mutually beneficial social being. Gender equality must exist, discrimination is never left to one another, everyone should be treated justly without any distinction of rights, and be entitled to their share without any reduction by anyone. In addition, Ethics also has a big role and influence in overcoming domestic violence, because ethics also helps people to take the attitude and act appropriately in living this life. Ultimately, ethics helps us make decisions about what actions we need and do not need to do. Ethics It is important to apply in all aspects or sides of life.

Darmastuti divides ethics as a study of philosophy into 2 (two) parts, namely:

a. General Ethics,

It is a moral principle that refers to basic moral principles as a guide in action and benchmark

to judge the good and bad of the actions that exist in society.

\section{b. Special Ethics,}

This is a basic moral application in a specialized field. someone decides to do and act ethically in some way

Gender inequality is the trigger of domestic violence (kdrt), the tendency to dominate, to be superior and to power against the opposite sex. The assumption is the most powerful of all women, resilient, not cowardly and not crybaby, while the opposite sex is due to the assumption that men are the supreme power holders in the family, as well as society, and women must respect and follow them all. Moral, ethics and values cannot be separated in society and life, because it becomes a series of spheres in human life. Good ethics produces good and unethical things that produce bad things. A polite and noble ethic not only gives sympathy to the affected person, but empathizes to provide moral and material assistance.

Attitudes born from the person of a man who often thinks he is very strong compared to women often leads to suffering and harm to the weak. The perception of the society that women are destined and the world born into as a male companion, and do not need a high education, 
because how also there is a term that we often hear "high school women will go to the kitchen as well" from a predicate as a housewife, who must always take care of husband and child, family ${ }^{3}$.

Violence is dominated by the social ethics that develops in society, which is seen from the reflection of one's behavior and words, assumes no distinction between each other, this directed must to be the broader society, by instilling a care and social ethics. character -minded. Prevention can be done the earliest that is the earliest age by growing awareness inside, both in men and women. The lack of ethics considered to be very influential on the character of poverty and foster and develop gender issues that will lead to criminal acts. Therefore, everyone must have self-awareness, especially the legal awareness in life.

\section{Conclusions}

Gender equality or gender inequality does not exist if each respects, understands rights and obligations, and is responsible. Social ethics in society leads to polite and well-spoken manner in which social ethics greatly influences how men can appreciate women, with the perception that same the has everyone degree, unintelligible social ethics can lead to violence, arguments, not even respect each other.

\section{Recommendations}

Women who experience acts of violence, whether in the scope of work or household, should immediately report, do not be kept quiet or hidden. Socialization of all people especially of women's the protection protection the rights is the responsibility of all levels of society along with the government apparatus and law enforcers.

${ }^{3}$ Elfi Muawanah, Pendidikan Gender Dan Hak Asasi Manusia, Teras, Yogyakarta, 2009, hal. 37-41 


\section{References}

Koesparmono Irsan, Hak Asasi Manusia Dan Hukum, Perguruan Tinggi Ilmu Kepolisian, Jakarta, 2004

Elfi Muawanah, Pendidikan Gender Dan Hak Asasi Manusia, Teras, Yogyakarta, 2009

Ridwan Mansyur, Mediasi Penal Terhadap Perkara KDRT, Yayasan Gema Yustitia Indonesia, Jakarta, 2010

https://www.zimlii.org/zw/journal/\%5Bnode\%3Afield_jpubdate\%3Acustom\%3AY/zimbabweelectronic-law-journal-vol-i-2016-all-volume 1 Tahun 2016 